\title{
条件推論・ワーキングメモリ・抑制制御の関連の発達的変化
}

中道 圭人

(東京学芸大学大学院連合学校教育学研究科)

Key words: 条件推論、ワーキングメモリ、抑制制御

条件推論は、条件命題と下位命題に基づいて論理的に正し い結論を導く推論である。条件推論の遂行は、ワーキングメ モリ（working memory: WM）と関連すると考えられている。 例えば Markovits \& Barrouillet（2002）は、条件推論が命題に 関するメンタルモデルを表象・操作することによってなされ るとし、そのメンタルモデルの基盤として WM を想定してい る。また、条件推論では、条件命題の内容が自分の経験に反 していても、それに基づいて推論しなければならない。その ため、条件推論には自分の知識を抑制するといった抑制制御 (inhibitory control: IC) 能力も関わっていると考えられる。こ の条件推論と $\mathrm{WM} ・ \mathrm{IC}$ の関連は児童期以降で検討されてきて いる。例えば、10 歳児を対象とした Handley et al. (2004) は、 $\mathrm{WM} \cdot \mathrm{IC}$ 課題の遂行が条件推論課題の遂行を予測することを 示している。それでは、これらの関連は発達的に変化してい くものなのだろうか。本研究では条件推論と WM・IC の関連 の発達的変化を明らかにするために、幼児一成人を対象にこ れらの関連を検討した。順唱課題・逆唱課題をWM、色単語 ストループ課題を IC 測定のために用いた。

\section{方 法}

対象者 : 幼稚園児 20 名 $(M=6: 2$ 、範囲 $=5: 9-6: 8)$ 。小学 3 年生 33 名 $(M=9: 5$ 、範囲 $=9: 0-9: 11)$ 、小学 5 年生 27 名 $(M=11: 4$ 、 範囲 $=10: 11-11: 10)$ 。大学生 81 名 $(M=19.84$ 歳、範囲 $=18$ 歳 -22 歳)。大学生の内、個別面接を受けた対象者は 20 名 $(M=19.84$ 歳、範囲 $=18$ 歳 -22 歳 $)$ 。

課題の手続き・採点方法 : (1)条件推論課題:条件命題と下位 命題から結論を導く課題。幼坚には個別面接法、それ以外に は質問紙法を用いた。経験的な条件命題（e.g., 泥遊びをした ら手が污れる）での課題（経験的課題）と、反経験的な条件 命題（e.g., 泥遊びをしたら手がきれいになる）での課題（反 経験的課題）があり、各対象者はそれぞれ 2 題、合計 4 題を 行った。各課題において、以下の 4 つの質問がなされた : 肯 定式 $=p \Rightarrow q, p$ （結論: $q ）$; 否定式 $=p \Rightarrow q$, not $-q$ （結論:not- $p$ ）；後 件肯定 $=p \Rightarrow q, q$ （結論:不定）; 前件否定 $=p \Rightarrow q$, not $-p$ （結論:不 定)。各質問に対して、論理的に正しい結論を述べた場合に 1 点を与えた（経験的・反経験的それぞれ 8 点満点）。また、肯 定式と否定式の合計得点を合理的推論得点、後件肯定と前件 否定を不定推論得点とした（各 4 点満点）。(2)順唱・逆唱課 題:個別面接法。数列を順唱あるいは逆唱する課題。数列は 2 -10 桁あり、各杵 2 試行ずつ行い、 2 試行とも失敗した時点 で課題を終了した。それぞれの桁で、2 試行成功の場合に 1 点、 1 試行成功の場合に 0.5 点を与えた (9 点満点)。 (3)色単 語ストループ課題:個別面接法。カードに描かれた色（赤/青/ 黄/緑） 24 個をそれぞれ命名する、あるいは、カードに書か れた色付きの色名単語 (e.g., 赤色で “きいろ”と書いてある) 24 個の色をそれぞれ命名する課題。干渉度（色名単語の色を 命名する時間一色を命名する時間）を IC 能力の指標とした。

\section{結果と考察}

条件推論課題に関して、年齢 $(4:$ 幼児· 3 年生 $\cdot 5$ 年生·大学 生） ×課題（2：経験的・反経験的） ×推論タイプ（合理的・ 不定)の分散分析を行った。その結果、年齢の主効果 $(F(3,157)$ $=109.24, p<.01)$ が有意で、大学生は他の 3 つの年齢群より、 小学 5 年生は小学 3 年生より得点が高かった。課題 $(F(1,157)$
$=39.70)$ と推論タイプ $(F(1,157)=369.32)$ の主効果がいず れも有意 $(p \mathbf{s}<.01)$ で、反経験的課題より経験的課題で、不 定推論より合理的推論で得点が高かった。さらに、二次およ び三次の交互作用がすべて有意であった $(p s<.01)$ これらの 交互作用を検討するため、課題・推論タイプ別の年齢による一 要因の分散分析を行ったところ、経験的課題での不定推論 $(F(3,157)=103.09: 3$ 年生 $<$ 幼児 $\fallingdotseq 5$ 年生 $<$ 大学生 $) 、$ 反経験 的課題での合理的推論 $(F(3,157)=11.55$ :幼児 $\fallingdotseq 3$ 年生 $<5$ 年

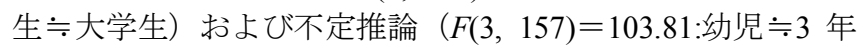
生 $\fallingdotseq 5$ 年生 $<$ 大学生) で有意な主効果 $(p s<.01)$ が見られた (図 1)。条件推論の発達は、推論タイプにより異なるようである。

次に、年齢別に各課題の相関係数を算出した（表 1)。その 結果、大学生を除いた他の 3 群において、条件推論課題と順 唱・逆唱課題には関連が見られた。従来の児童での研究 (e.g., Handley et al., 2004） と同様、児童の条件推論遂行に WM が関 わっており、その関連は児童期だけでなく幼児期から見られ ることが示されたといえる。

さらに、幼児と小学 3 年生では反経験的課題と干涉度に負 の相関が見られた。Handley et al. (2004) での対象者より年 少の子どもでも、反経験的な条件推論遂行に IC 能力が関わっ ているようである。しかし、反経験的な条件推論と IC の関連 は小学 5 年生や大学生では見られず、この関連は発達的に変 化するといえる。前述のように、反経験的な合理的推論の遂 行は、小学 3 年生から小学 5 年生にかけて向上していた。経 験的な合理的推論の遂行が幼児一成人にわたり良かったこと を考えると、反経験的な推論の困難さの原因の 1 つは、経験 的情報を抑制できないことにある。小学 5 年生や大学生は経 験的情報の抑制に必要とされる IC 能力を十分に兼ね備えて おり、容易に経験的情報を抑制できるため、反経験的な条件 推論と IC の関連が見られなかったのかもしれない。

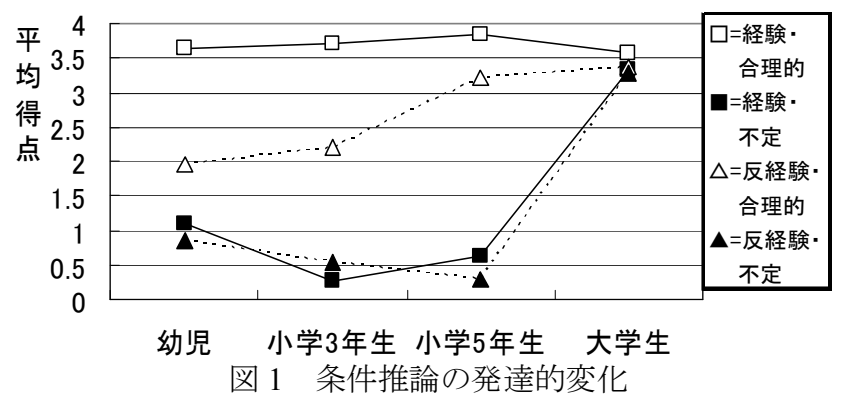

表1 年齢別の各課題の相関係数

\begin{tabular}{|c|c|c|c|c|}
\hline 年齢 & 条件推論課題 & $\begin{array}{l}\text { 順唱 } \\
\text { 課題 }\end{array}$ & $\begin{array}{l}\text { 逆唱 } \\
\text { 課題 }\end{array}$ & $\begin{array}{l}\text { 抑制制御 } \\
\text { (干渉度) }\end{array}$ \\
\hline \multirow{2}{*}{$\begin{array}{c}\begin{array}{c}\text { 幼児 } \\
(n=20)\end{array} \\
\text { (n) }\end{array}$} & 経験的課題 & 33 & $.46^{*}$ & .09 \\
\hline & 反経験的課題 & $.50 *$ & $60^{* *}$ & $-.45^{*}$ \\
\hline \multirow{2}{*}{$\begin{array}{c}\text { 小学3年生 } \\
(n=33)\end{array}$} & 経験的課題 & $.45^{*}$ & .04 & $.40^{*}$ \\
\hline & 反経験的課題 & .17 & .14 & $-.58^{* *}$ \\
\hline \multirow{2}{*}{$\begin{array}{c}\text { 小学5年生 } \\
(n=27)\end{array}$} & 経験的課題 & $.38^{*}$ & $.36^{\dagger}$ & -.25 \\
\hline & 反経験的課題 & $.40^{*}$ & $.33^{\dagger}$ & -.26 \\
\hline \multirow{2}{*}{$\begin{array}{l}\text { 大学生 } \\
(n=20)\end{array}$} & 経験的課題 & .31 & .19 & -.07 \\
\hline & 反経験的課題 & .21 & .29 & .12 \\
\hline
\end{tabular}

(NAKAMICHI Keito) 